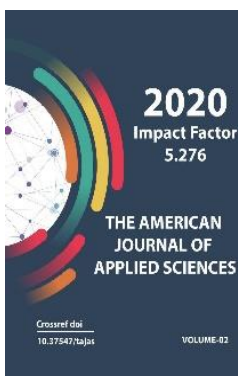

\title{
Using Model Of Intellegent Jadids In The Propoganda Of Education And Enlightenment
}

\author{
Sabirova Zilolaxon Mahmudovna \\ Head Of The Master's Department Of Fergana State University, Deputy Of Fergana City \\ Council, Uzbekistan
}

\begin{abstract}
Copyright: Original content from this work may be used under the terms of the creative commons attributes 4.0 licence.
\end{abstract}

\section{ABSTRACT}

The article puts forward ideas in an intensive pilgrimage work, and now they support the use of ideas in education and enlightenment. They also covered the political activities of the jadids.

\section{KEYWORDS}

Education, Enlightenment, Jadid, Pan-Turkism, Pan-Islam, Equality, Justice

\section{INTRODUCTION}

In today's world, which the it is changing so rapidly and several new threats and dangers are hazarding stability and development of nations, paying attention to spirituality and enlightenment, moral education, education and development of young people is becoming more important issue than last.

Education and enlightenment are considered as the main factors of human well-being, encourage people to geneality generous patience encourages contentment.[1]Enlightenment is a unique power that make the world liberty and flourishing, extricate person from the omphalos of vandalism and superstition,able to solve its spiritual and economic problems. At the end of XIX centuryat the beginning of $X X$ century in order to awake and show the truth to being dependent of the Russian Empire and completely declined Turkistan country, the enlightenment movement became stronger than ever during this period, as it could only be achieved through it. The enlightenment movement that was born as necessity of renewal society was made up of progressive intellectuals who set out to solve a number of social, political, legal and spiritual problems - which went down in history as the Jadid movement.By making the people enlightened Jadids consider forming national independence idea and organizing drastic reformation as a prior duty. But this 
action marked negatively during soviet tyrannical system.

Before the perilious period achieveing independence the first President of Uzbekistan Islam Karimov points the principal ideas, "Our enlightened ancesters are a practical way to rationally put an end to the long-running controversy over the attitude to the life and work of the representatives of Jadidism and to return their heritage to our people.[2]From this point of view, the study of the influence of the philosophical and moral views of the Jadids on the formation of patriotic education is one of the most emphasizing issues today.

\section{MATERIALS AND METHODS}

The purpose and essence of the Jadid movement is also known from its motto. Munavvarqari, the spiritual and ideological father of the nation in his time, showed that the favorite motto of the Jadids was "Freedom, Equality and Justice." Jadids, Jadidism was a conscious culturalenlightenment, socio-political, anti-feudal and democratic action against colonialism.

The life of the Jadids is one of the important tasks is to study the path of struggle they have gone throughimportant for us in educating the youth in the spirit of independence, patriotism, nationalism, humanity.

In general, Jadid intellectuals realized the need to improve national consciousness in order to achieve freedom and independence. They desired to make a practical awakening through this. This was cosidered as education and upbringing in enlightenment. That is why the Jadids worked tirelessly to establish a new system of education and upbringing. [3]

In the Turkistan Jadid movement and its ideological heritage, the ideas of independence and national patriotism were intertwined with common democratic values.
The political programs of the Jadids were desired to achieving for the independence of Turkistan. They believed that their political demands were be able to establish a constitutional monarchy. That is why they discussed the programs of the parties involved in the political struggle and approved the program of the cadet's party. [4]

Mahmudhoja Behbudi, while advancing his ideas of national independence, expressed his attitude to various parties and agitated to support for the cadets. Behbudi emphasized his sympathy for the Muslim Party, which was founded in 1905. "Although this party is close to the cadet party in terms of its general political demands and beliefs, it was formed to protect the interests of Muslims," Behbudi said. "Therefore, we, the Muslims of Turkistan, must join the Muslim Party when we use cadets in politics. Serving to this party, to beits supporter, is serve our religion, our country and our nation." [5]

Jadidism was not just an enlightened, culturalenlightenment movement. Soviet politicians understood it clearly. They would not berepressed if it was just an action.They were not announced as "people's enemy" or "traitors." By the way, it is not difficult to relieze this even in our historians who have been claiming "truth". AV Pyaskovsky writes: "From that time (1905-1917) the bourgeoisliberal, nationalist movement known in Turkistan as" Jadidism "began to spread, and the method went beyond the initial narrow circle of Jadid schools, such as the opening and promotion of culture. It has acquired a clear political significance. "[6] Indeed, Jadidism could not be unrelated to political movements. In order to understand clearly the issue, it is necessary to look at its history one more time. In general, after the Russian invasion, there were many popular riots in the country. Most of them were attempts to gain independence. However, the organizing was weak and was often religiously motivated. In general, this 
movement, which shook the whole of Turkistan with its expanse and consequences, and its interpretation in literature, are among the issues that need to be studied in collaboration with our historians and literary critics. The events of at the begining of the century, the defeat in the Russo-Japanese War, brought Russia to a crisis. Internal national conflicts and protests started to intensify. But the subjugated nations began to realize that it was no longer right to fight for their rights as before. A gradual awakening began in Turkistan as well. In Russia, especially in the Caucasus, there is a growing desire for rapprochement and cooperation with the Turkic peoples living in the Volga region. New ideas began to come in. Islamism (panIslamism) and Turkism (pan-Turkism) were among them. These ideas emerged in the Ottoman state in the mid-nineteenth century. Initially, "Ottomanism" was introduced.

\section{RESULT AND DISCUSSION}

It turns out that in his time, thereupon to chauvinist Turkologists such as NI Ilminsky (1822-1891), he became famous as a missionary center. In the last months of 1908 , the rector of the Religious Academy in Kazan, Hazrat Alexei, received a long report from the Russian Interior Ministry on "Modern Movements among Russian Muslims," which said that something called pan-Islamism was spreading among Muslims. In this regard, the government has set up a special commission in the Department of Non-Religious Affairs to study the Muslim movement. It was, in the words of S. Maqsudi, a commission to develop measures against the national action of Muslims. The opening of schools and the publication of newspapers and magazines among Russian Muslims were cited as the main evidence of the accusation of "pan-Islamism." [7]

Sadri Maksudi returned to the issue again in 1912 at one of the meetings of the 3rd Duma. Here is an excerpt from a speech published in
Time (1912, No. 955): “... I say repeatedly, gentlemen, we do not have any action against the state. We have only a wish: to be a fullfledged free citizen of the great Russian Empire ... I think there is no contradiction between our national life and the Russian state. We will always accompany the Russian citizen in the general affairs of our country, who is praying for the progress and development of the Russian state. But within our own family and nation. Give us the freedom to live in the world, preserving the sacred things that our people have bequeathed to us and bequeathed to us, and to live in the world as our united national spirit has wished for centuries."[8] It is not difficult to understand that the restriction of the rights of the Turkic peoples in the kingdom and the Russification were intensifying due to the guilt of Pan-Islamism.

\section{CONCLUSION}

The ideas of Jadidism, like the fierce winds of early spring, exposed the tumultuous medieval life to the lowest strata. The issue of life and death of the nation and the Motherland to be put on the agenda was announced. Education, press and theater in the heart of Turkistan gave life to the saplings. At the heart of these ideas was the national renovation, the struggle for national independence. The essence of Jadidism was an exciting process ranging from understanding the nation and the homeland to fighting for their interests. At the same time, this movement also brought up the nation. He raised it to the point where he could analyze every calamity that befell him, from interpreting it as destiny, and seeking a remedy. In particular, our Jadids realized that in order for the nation to live and develop, it was necessary, first of all, to be free and independent, and they paid special attention to awakening the broad masses. Our Jadids were regularly engaged in political affairs - the rule of law, the nation-state, the government. Meanwhile, school education began to be reformed. The national press was set up. The 
theater appeared. New literature was formed, in a word, new thinking emerged. This was undoubtedly unprecedented in the historical development of the nation over the next 3-4 centuries. Long in his life. was a sign of the beginning of a new period after the recession.

The issues of the TurkistanJadid movement are still reflected in our legislation on the basis of historical heritage and tradition. Hence, the study of fiqh-legal relations in this doctrine is a modern requirement. This doctrine is of great importance in preserving our national values, traditions and customs, instilling in the hearts and minds of our people, especially the younger generation, a deep love for the motherland and devotion to independence. They play an important role in forming a sense of respect for national and universal values.

\section{REFERENCES}

1. Mirziyoev Sh.M. We will resolutely continue our path of national development and raise it to a new level 1., Tashkent "Uzbekistan" - 2018 page 28

2. Karimov I.A. Uzbekistan is on the verge of independence. -T .: Uzbekistan, 2011. Pages 20-21.

3. Imomnazarov $M$ "Fundamentals of Spirituality" Tashkent. "Sharq" 2001 Page 131.

4. Encyclopedic Dictionary "Philosophy", Publishing House of the National Society of Philosophers of Uzbekistan. T., 2004

5. Encyclopedic Dictionary "Philosophy", Publishing House of the National Society of Philosophers of Uzbekistan. T., 2004

6. Pyaskovskiy A. V. Revolyutsiya 1905-1907 godovv Turkistane, M., 1958. Page 543

7. Qosimov B. "National Awakening" T, "Sharq" 2000, 25 pages.

8. Qosimov B. "National Awakening" T, "Sharq" 2000, 53 pages.

9. Мирзарахимов, Б. Х. (2019). КУЛЬТУРА ТУРИЗМА КАК СТРАТЕГИЯ РАЗВИТИЯ
КНИГОВЕДЕНИЯ. InПЕРСПЕКТИВНЫЕ ОБЛАСТИ РАЗВИТИЯ НАУКИ И ТЕХНОЛОГИЙ (рр. 57-58).

10. Mirzarahimov, B. (2019). The factor of good neighborhood and tourism development (Philosophical analysis). Scientific Bulletin of Namangan State University, 1(1), 140145.

11. Mirzarahimov, B. H. (2020). The Tasks Of Tourism In Aesthetic Education: The Harmony Of Historicity And Modernity. The American Journal of Social Science and Education Innovations,2(09), 652-658.

12. Mirzarahimov, B. (2019). The factor of good neighborhood and tourism development (Philosophical analysis). Scientific Bulletin of Namangan State University, 1(1), 140145.

13. Mirzarakhimov, B. (2020). Tourism-is a modern means of aesthetic education. СБОРНИК СТАТЕЙ.

14. Madimarovna, A. I., \& Khoshimovich, M. B. (2020). Factors for the development of tourism culture in the uzbek national value system.ACADEMICIA: An International Multidisciplinary Research Journal,10(4), 575-580.

15. Madimarovna, A. I. (2020). The Role of Art in Youth's Aesthetic Education. CrossCultural Communication, 16(1), 121-123.

16. Arzimatova, I. (2019). Art industry development of society and society culture. Scientific Bulletin of Namangan State University,1(1), 129-134.

17. Arzimatova, I. (2019). AESTHETIC EDUCATION, ITS FEATURES AND STRUCTURE. Scientific Bulletin of Namangan State University, 1(6), 219-222.

18. Sobirova, Z. (2020). Hoarding and Opportunistic Behavior During Covid-19 Pandemics: A Conceptual Model of NonEthical Behavior.International Journal of Management Science and Business Administration, 6(4), 22-29.

19. Mahmudovna, S. Z. (2020). The Role Of Sufism Teaching In Spiritual Education Of Youth. The American Journal of Social 
Science and Education Innovations, 2(08), 553-556.

20. Arzimatova, I. M. (2019). THE PROCESS OF GLOBALIZATION AND THE FORMATION OF SENSE OF PATRIOTISM IN YOUNG PEOPLE. In PROSPECTIVE SCIENCES AND TECHNOLOGIES (pp. 20-22).

21. Arzimatova, I. M. (2020). Art as a kind of education. Bulletin of Pedagogy: Science and Practice, (51), 116-117.

22. ARZIMATOVA, I., \& MUMINOV, J. (2019). ROLE AND SIGNIFICANCE OF AESTHETIC MORALITY IN THE PROCESS OF IMPROVING YOUNG GENERATION. BBK 60 O 23, 60.

23. ARZIMATOVA, I., \& MUMINOV, J. (2019). SECTION "PHILOSOPHICAL SCIENCES". BBK 60 A 43, 234.

24. Arzimatova, I. M. (2016). On the question of the creative potential of the national aesthetic culture in civil society. Young Scientist, (3), 1112-1114.

25. Madimarovna, A. I. (2020). The Role of Art in Youth's Aesthetic Education. CrossCultural Communication, 16(1), 121-123.

26. Arzimatova, I. (2019). Art industry development of society and society culture. Scientific Bulletin of Namangan State University,1(1), 129-134.

27. Arzimatova, I. (2019). AESTHETIC EDUCATION, ITS FEATURES AND STRUCTURE. Scientific Bulletin of Namangan State University, 1(6), 219-222. 